\title{
Reed Canary Grass for Energy in Sweden: Yields, Land-Use Patterns, and Climatic Profile
}

\author{
Blas Mola-Yudego ${ }^{1,2, * \mathbb{D}}$, Xiaoqian $\mathrm{Xu}{ }^{1, * \mathbb{D}}$, Oskar Englund ${ }^{3}$ and Ioannis Dimitriou ${ }^{2}$ \\ 1 School of Forest Sciences, University of Eastern Finland (UEF), P.O. Box 111, FI-80101 Joensuu, Finland \\ 2 Department of Crop Production Ecology, Swedish University of Agricultural Sciences (SLU), \\ 75007 Uppsala, Sweden; Ioannis.Dimitriou@slu.se \\ 3 Department of Ecotechnology and Sustainable Building Engineering, Mid Sweden University, \\ 83125 Östersund, Sweden; oskar.englund@miun.se \\ * Correspondence: blas.mola@uef.fi (B.M.-Y.); xiaoqian.xu@uef.fi (X.X.)
}

Citation: Mola-Yudego, B.; Xu, X.; Englund, O.; Dimitriou, I. Reed Canary Grass for Energy in Sweden: Yields, Land-Use Patterns, and Climatic Profile. Forests 2021, 12, 897. https://doi.org/10.3390/f12070897

Academic Editor: Timothy A. Martin

Received: 26 April 2021

Accepted: 30 June 2021

Published: 9 July 2021

Publisher's Note: MDPI stays neutral with regard to jurisdictional claims in published maps and institutional affiliations.

Copyright: (c) 2021 by the authors. Licensee MDPI, Basel, Switzerland. This article is an open access article distributed under the terms and conditions of the Creative Commons Attribution (CC BY) license (https:// creativecommons.org/licenses/by/ $4.0 /)$.

\begin{abstract}
Research Highlights: (1) Reed canary grass (RCG) is analysed in Sweden compared to willow and poplar for 2001-2020. (2) Each crop presents a different land-use and climatic profile. (3) Average yield records of RCG are similar to willow and poplar. (4) There are divergences between trial-based and commercial yields. (5) Existing land-use change patterns suggest meadow $>$ RCG and RCG > cereal. (6) RCG land area is very sensitive to policy incentives. Background and objectives: RCG is an alternative crop for biomass-to-energy due to high yield and frost tolerance. We assess the cultivation in Sweden by using an extensive compilation of data, with emphasis on the extent of the cultivation, climatic profile, land-use patterns, and productivity. Material and methods: RCG plantations are analysed for 2001-2020. A geostatistical analysis is performed to characterize where it is cultivated and the land uses associated. Climatic, productivity, and yield profiles are compared to willow and poplar plantations from experiments and from commercial plantations. Results: The results show that the cultivation of RCG expanded after 2005, with a maximum of 800 ha in 2009, to then decrease to the current levels of about 550 ha. It is mainly grown in colder climatic areas, with lower agricultural productivity than willow and poplar. Mean yields from trials are 6 oven dry tonnes (odt) ha ${ }^{-1}$ year $^{-1}$; commercial yields are 3.5 odt ha $^{-1}$ year $^{-1}$. RCG replaces meadow land and then is replaced by cereals when abandoned. Conclusions: RCG is an interesting alternative with similar yields (commercial and trials) as other energy crops, but its success is more sensitive to policy incentives.
\end{abstract}

Keywords: energy crops; land use; biomass; bioenergy; reed canary grass (RCG); Phalaris arundinacea L.

\section{Introduction}

Perennial grasses have been considered as promising energy crops due to several characteristics that make them attractive for intensive biomass production compared to annual crops, i.e., high yield potential, high lignin and cellulose contents in their biomass, high heating value, low water content, lower management inputs such as soil tillage, and others [1]. They also offer advantages compared to perennial trees for energy since they do not need special equipment for management practices and can use common existing equipment for annual crops. In addition, they can enhance conditions for biodiversity and provide several ecosystem services, e.g., phytoremediation, erosion control, enhanced soil organic carbon, mediation of water flows, and retention of nutrients and other agrochemicals [2-4].

Among them, reed canary grass (RCG) (Phalaris arundinacea L.) has shown a great energy potential in Europe for direct combustion; as a feedstock for pellets and other solid biofuels [5]; in biochemical technologies like bioethanol and biogas [6,7]; in other thermochemical applications, like pyrolysis [8]; and additional added value applications being currently considered [9]. In Northern Europe, RCG has been used at a commercial 
level in Finland [10-12] and Sweden [13,14], presenting advantages due to its frost resistance and adaptability potential to hard climatic conditions. In Sweden, its use has been documented since 1749 for forage in Scania, and studies in the 1800s highlighted its high yield potential, particularly in the northernmost areas [15]. In the 1980s, research was performed aiming to grow RCG as an alternative biomass source for the pulp industry [16] and later for large-scale industrial production for energy [17]. In fact, it was considered as one of the most interesting energy crops in the country [18], and in the early 2000s, new varieties started to be dedicated exclusively for this purpose [19]. Since then, RCG has been established along the whole country [18] in large stands with a height of about 1.5-2 $\mathrm{m}$. The main commercial varieties have been Palaton and Venture and, more recently, Bamse [17].

Crop management activities are regarded as easier compared to other lignocellulosic energy crops, such as willow and poplar, with lower establishment costs due to the use of existing conventional equipment and the use of seeds in the establishment phase [20]. Under Swedish conditions, the soil is prepared by ploughing before sowing. Perennial weeds, such as couch grass, are controlled the previous year. Sowing occurs in early spring with a row spacing of $10-15 \mathrm{~cm}$. Growth is rather slow in the beginning until the root system is established, and weeding could be necessary during the first year. The first harvest occurs the second year after sowing, and a well-managed field can be productive for 10-15 years before re-establishment is required [17]. RCG grows well on most kinds of soils but particularly in poorly drained soils, as it tolerates waterlogging better than many other grasses [21]. Due to its deep root system once well established, it is also more drought-resistant than other grasses [1].

In the 1990s, the fertilisation recommendations were 150, 100, and $30 \mathrm{~kg}$ per hectare nitrogen $(\mathrm{N})$, phosphorus $(\mathrm{P})$, and potassium $(\mathrm{K})$, respectively, in the first year, and 80, 30, and $10 \mathrm{~kg}$ per hectare during the rest of the production period [19]. In recent decades, this has been changed to 40,15, and $50 \mathrm{~kg}$ in the year of sowing; 100, 15, and $80 \mathrm{~kg}$ the following year; and 50,5, and $20 \mathrm{~kg}$ in spring [22]. To reduce fertilisation costs, the application of mixtures of sewage sludge, wood, and grass ash have also been practiced [19,23]. Harvest takes place in the second year after sowing, preferably in early spring because the grass presents the lowest moisture content (ca. 10\%-15\%) and can be used in power plants without drying. The first harvest can be $20 \%$ lower than subsequent harvests $[17,19]$. Moreover, sodium $(\mathrm{Na}), \mathrm{K}$, and chlorine $(\mathrm{Cl})$ concentrations are the lowest in early spring, which makes it a better fuel with decreased corrosion risks for the boiler [17]. Harvesting is a critical operation, as increasing the harvest height from $5 \mathrm{~cm}$ to $10 \mathrm{~cm}$ can result in harvest losses exceeding $25 \%$ of biomass [24]. In general, ordinary hay harvesting equipment is used, and transportation from the field usually occurs in bales. The final removal of the crop is often performed by conventional soil tillage operations [19].

As a perennial grass, RCG can complement the options for energy crops in the country, today largely based on woody plantations. In this sense, research has been focused on trials and management regimes (e.g., [25,26]), the biology of the crop (e.g., [27]), and even biomass properties for energy use (e.g., [28]). However, despite its current commercial use, there have been few attempts to provide a comprehensive assessment of the cultivation, especially with regards to the other lignocellulosic energy crops grown for similar purposes, and the land use changes in the areas cultivated, linked to the policy framework. This paper analyses the present situation of RCG cultivation in Sweden using an extensive compilation of records, with emphasis on the current extent of the crop, land-use change patterns, and overall productivity. The main goal is to assess its performance and development compared with other biomass production systems, such as willow, poplar, or hybrid aspen, in order to better define its role in the mix of energy crops.

\section{Material and Methods}

\subsection{Data Sources}

Several databases for agricultural production were combined for the analysis. The location of the commercial plantations for the period 2001-2017 was retrieved from the 
land register using the IACS (Integrated Agricultural Control System) database maintained by the Swedish Board of Agriculture. This database permits to extract the land use of each polygon (blocks in the databases), defined as a uniform land area that remains quite constant from one year to the next [29] although the use of the land may be altered. Land-use data from 2001 to 2016 were included in the analysis. The method to deal with the land uses was based on Xu and Mola-Yudego [30]. The total area cultivated for 2017-2020 was retrieved from Statistics Sweden but, in this case, was aggregated.

A database of existing trials was constructed, including records from RCG, willow, and poplar/hybrid aspen (given the limited area planted, in this paper, will be referred together). For RCG, trial records were retrieved from Landström et al. [18], Lindvall et al. [23], Nilsson et al. [14], Lindvall et al. [25], and Lindvall [21] during the period 1991$2015(\mathrm{~N}=201)$. For willow, a trial database was used based on Mola-Yudego et al. [31] $(\mathrm{N}=290)$ and for poplar, from Dimitriou and Mola-Yudego [32] $(\mathrm{N}=58)$. In the case of RCG, the observations were annual harvests, whereas for willow and poplar, they were the annual yield of the biomass produced during the cutting season or rotation (4-20 years). Concerning commercial records, the annual yield for RCG for Sweden was extracted from the Eurostat database [33] as well as from records supplied by Statistics Sweden and, for Finland, from Luke [34].

To analyze the agricultural profile of the cultivations, the data was based on the standard yield estimates by agricultural districts [35]. For the climatic profile, data were retrieved from the WorldClim database for Sweden using the last standard period 1960-1990 at a resolution of $1 \times 1 \mathrm{~km}$ for the monthly minimum and maximum temperatures and precipitation [36].

\subsection{Data Analysis}

All plantations of RCG existing in Sweden were identified and geo-located for the period 2001-2017. The series was completed till 2020 with the aggregated area available. The total cultivated area and the average size of the plantations were quantified for each year during that period and compared to similar records of willow and poplar. The geographical distribution of the plantations was further analysed by using spatial kernel methods $[37,38]$. Kernel density estimation is a non-parametric method that allows to define core areas (areas with the highest density of the crop) and home areas (area entailing most of the cultivated area). The method was applied following Mola-Yudego and GonzálezOlabarria [39]. The core area was the smallest area to include $50 \%$ of all existing plantations for a given period, and the home area defined the area including nearly all plantations (90\%). The same analysis was performed to willow and poplar plantations.

For each plantation, monthly estimates of temperature (maximum and minimum) and precipitation were calculated in order to provide a climatic profile. The monthly mean values for all plantations were then averaged for the whole country in order to provide a climatic profile for each biomass production system. Similarly, the estimated standard yield of cereals was used as an indicator of land productivity. Among the options, barley is the most common crop in most areas where plantations are established. To reduce the effect of climatic variations on specific years, the average was estimated for several years (2003-2017) using the same approach as in Xu and Mola-Yudego [30]. This yield was assigned to each plantation, and the country's average was calculated on a yearly basis for the three main plantation systems in the same way as for the climatic variables.

The productivity of RCG were assessed using yield records from trials and commercial yields and compared to the performance of the other plantation systems. The estimates from experimental plots were investigated by observing the ranges and geographical distribution of the trials compared to the equivalent levels of willow and poplar from similar trials and experimental plots. These values were also contrasted to the official averages resulting from commercial plantations both in Sweden and in nearby areas in Finland. 
Finally, changes in land uses were also investigated; prior land uses in each plantation were identified and grouped in three main categories (cereal production, fallow land, and meadows), and the changes in area were estimated annually.

\section{Results}

Prior to the data available in the land registry, there were records of ca. 4000-5000 ha sown with RCG in 1991, which were mainly dedicated to forage and animal use [17]. These plantations nearly disappeared by the end of the 1990s, as the area under cultivation was around 675 ha in the first year of detailed records. After 2005, the area increased significantly to 800 ha in 2009 (Figure 1), mainly for energy purposes. Prior to this year, RCG could get support only when there was a contract for industrial use (mainly energy) when grown on land without support rights for set-aside land [40]. This level lasted until 2013; after that, there was a steady decline in the area to the most recent figure (ca. $550 \mathrm{ha}$ ). The distribution of the size of the fields followed a logarithmic distribution with the prevalence of small plantations over large ones. Fields larger than 5 ha were uncommon and over 10 ha were very rare. The average plantation size increased over time from ca. 2.18 ha in 2005 to 2.4 ha until recent years.
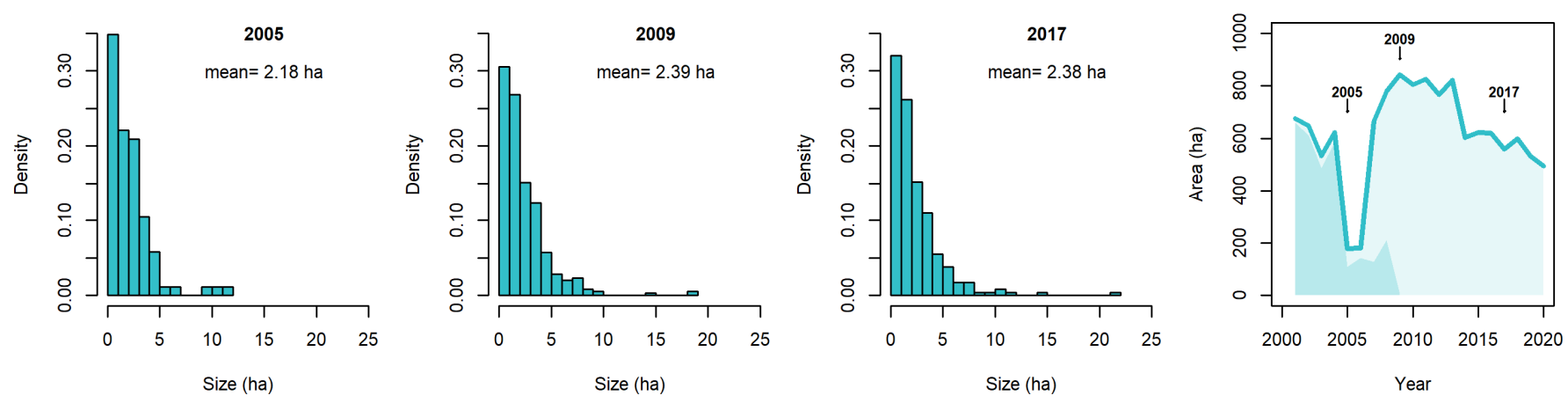

Figure 1. Evolution of area cultivated with reed canary grass land for the period 2001-2020 and distribution of the plantations according to their size. Shaded area refers to non-contractual plantations (largely before 2009).

Although RCG plantations are distributed along the whole country, the largest concentration is at the northeast, around the regions of West and North Bothnia and, to a lesser extent, in the central and southern parts of the country, where the share of agricultural land is larger, and other lignocellulosic energy crops, such as willow and poplar, are typically planted (Figure 2).

The geographical location of the plantations is reflected in the climatic profiles. The mean annual precipitation of a plantation of RCG in Sweden was $582 \mathrm{~mm}$ compared with $605.5 \mathrm{~mm}$ and $654.7 \mathrm{~mm}$ for willow and poplar aspen, respectively. The mean annual temperatures were between $-0.44{ }^{\circ} \mathrm{C}$ (minimum) and $7.56^{\circ} \mathrm{C}$ (maximum), which represents a colder average than the $2.78^{\circ} \mathrm{C}$ (minimum) and $9.99^{\circ} \mathrm{C}$ (maximum) for willow and $3.16^{\circ} \mathrm{C}$ (minimum) and $10.05^{\circ} \mathrm{C}$ (maximum) for poplar (Figure 3 ). 

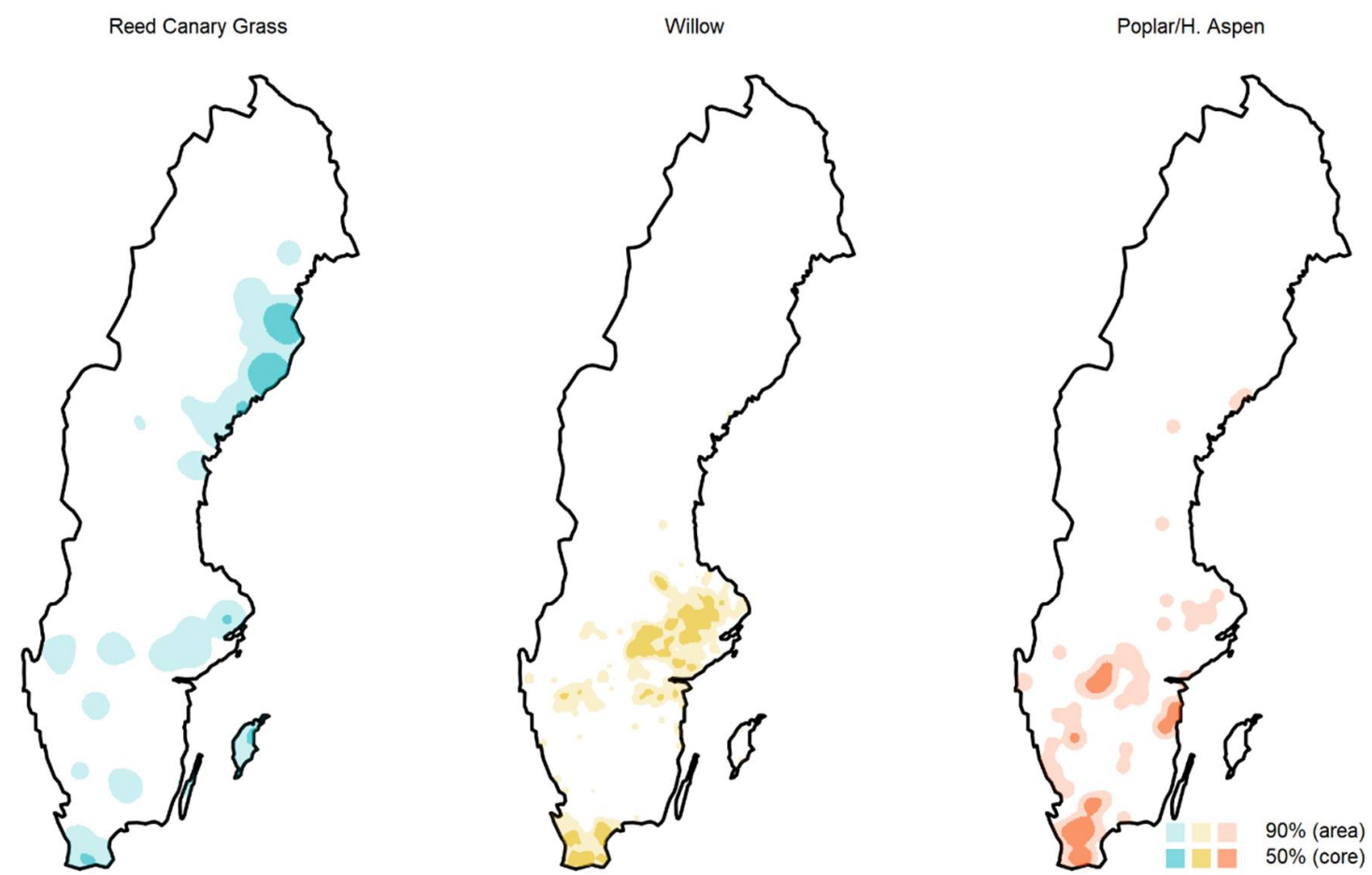

Figure 2. Location of reed canary grass plantations in Sweden, including all fields and extension of the cultivation area and core areas with the highest concentration of plantations compared to willow and poplar/hybrid aspen for the same year.
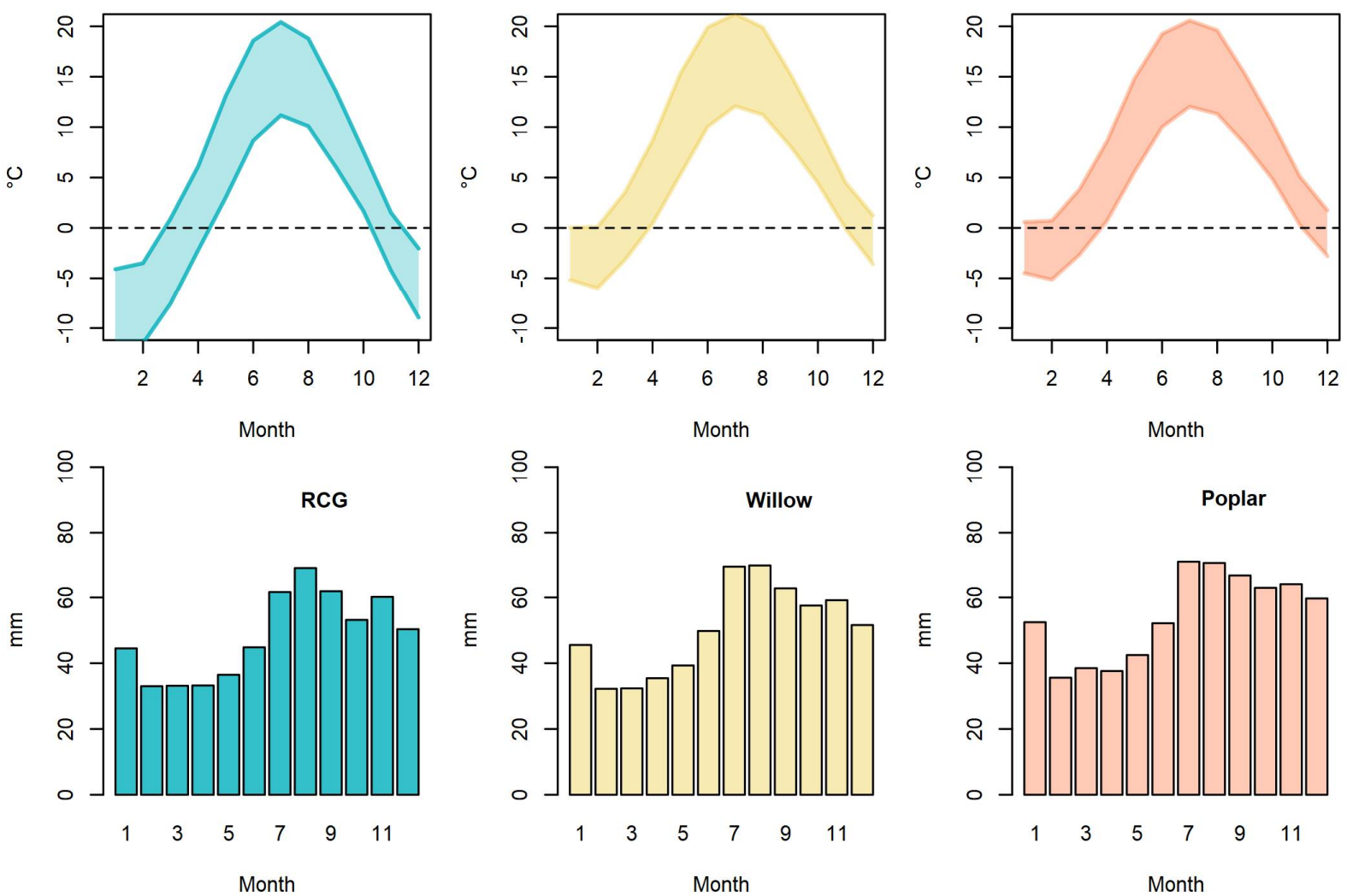

Figure 3. Agro-climatic profile of reed canary grass (RCG) compared to other fast-growing plantations in Sweden. The profiles represent the mean monthly maxima and minima temperatures and precipitation records of all plantations of RCG $(\mathrm{N}=350)$, willow $(\mathrm{N}=3305)$, and poplar/hybrid aspen $(\mathrm{N}=253)$ for a reference year $(2009)$. 
The analysed trials represent the geographical distribution of the commercial plantations (Figure 4), and the results show large ranges. The maximum record from the trials is close to 15 oven dry tonnes (odt) ha ${ }^{-1}$ year $^{-1}$ (comparable to poplar). Yields over 10 odt ha ${ }^{-1}$ year $^{-1}$ are more common in the case of willow plantations. In general, the mean yields from trials for RCG, willow, and poplar are similar despite the fact that RCG is often located in less favourable climatic areas, with lower average agricultural productivity (Figure 4).
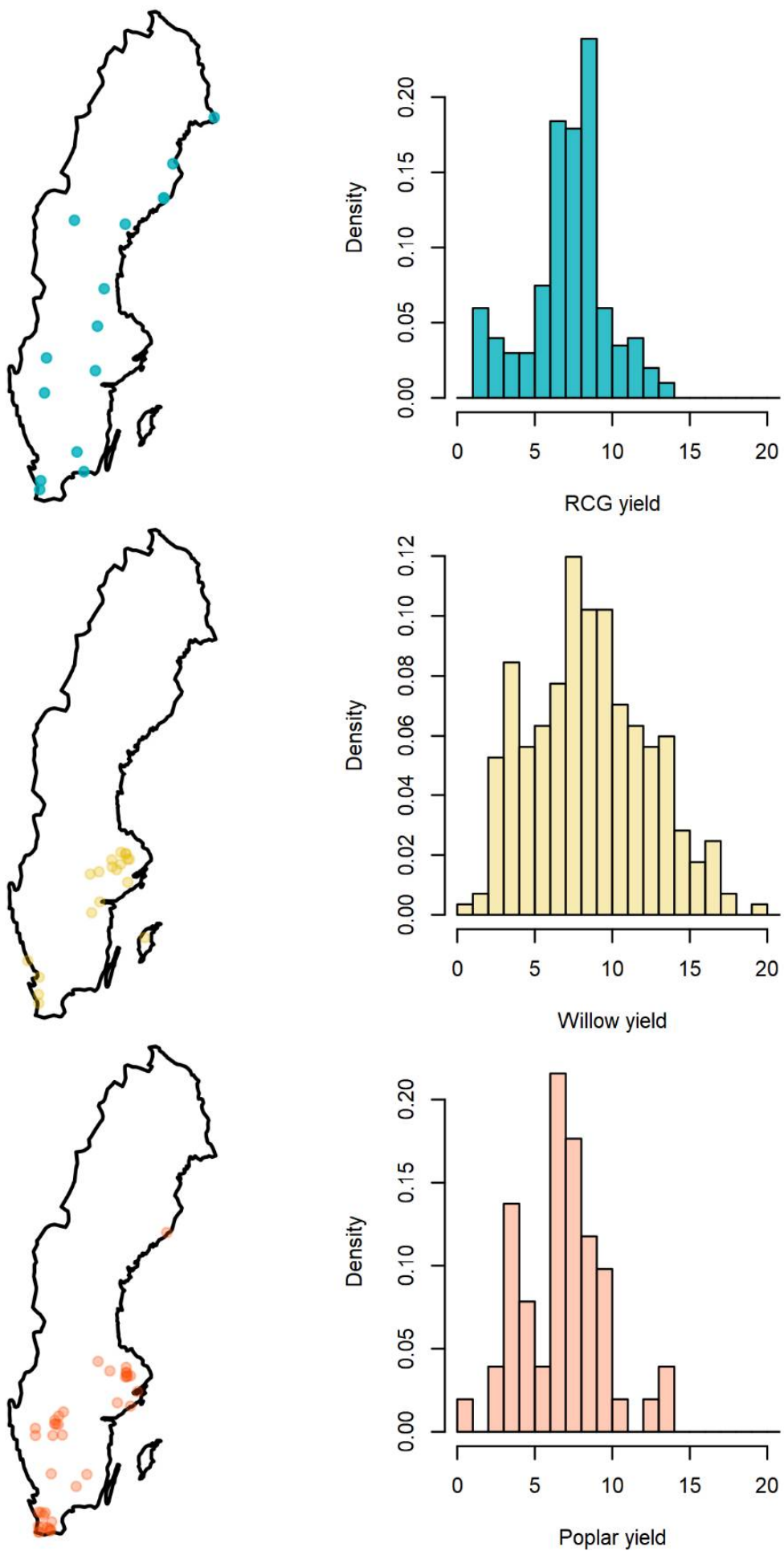

Figure 4. Estimated distribution of yields ( $\mathrm{odt} \mathrm{ha}^{-1} \mathrm{year}^{-1}$ ) for reed canary grass compared to willow and poplar in different trials along the country (see maps) for the period of 1991-2010. 
The yields from trials, however, are largely overestimating the commercial yield of RCG, estimated around 3.37 odt ha $^{-1}$ year $^{-1}$ in Sweden (Figure 5). Nearby areas in Finland present similar values for commercial plantations, for example, around 3.6 in Lapland and 4.2 in South Ostrobothnia. The Finnish average is even lower $\left(3.1 \mathrm{odt} \mathrm{ha}^{-1}\right.$ year $\left.^{-1}\right)$. The corresponding values for commercial willow plantations in Sweden are $2.6 \mathrm{odt} \mathrm{ha}^{-1}$ year $^{-1}$ and $4.2 \mathrm{odt} \mathrm{ha}^{-1}$ year $^{-1}$ for the first and second rotation, respectively.
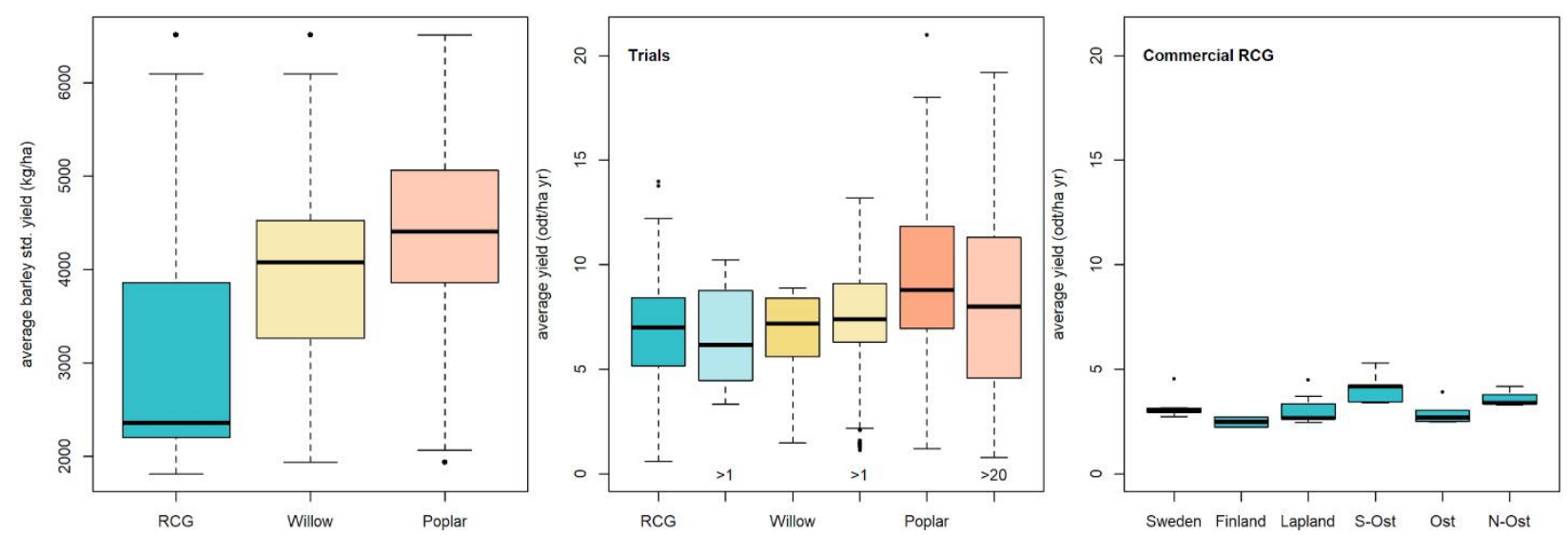

Figure 5. Land productivity yields of the trials for reed canary grass (RCG), willow, and poplar in Sweden. Left: Averaged agricultural productivity of all established plantations using the standard yields of barley by agricultural district. Centre: Average yield (oven dry tonnes, odt) from trials in Sweden for reed canary grass (1991-2010), willow (1986-2004), and poplar (1980-2015), where $>1$ refers to second harvest and subsequent and $>20$ refers to plantations over 20 years. Right: Average yield for RCG (odt) from commercial plantations for the period 2011-2017 in Sweden and Finland (counties: Lapland, South Ostrobothnia, Ostrobothnia, and North-Ostrobothnia).

Finally, changes in land use show that RCG is mainly replacing meadow and cereal land, in that order, starting in 2005. However, after 2009, RCG plantations were replaced by cereals to a larger extent than meadows (Figure 6).
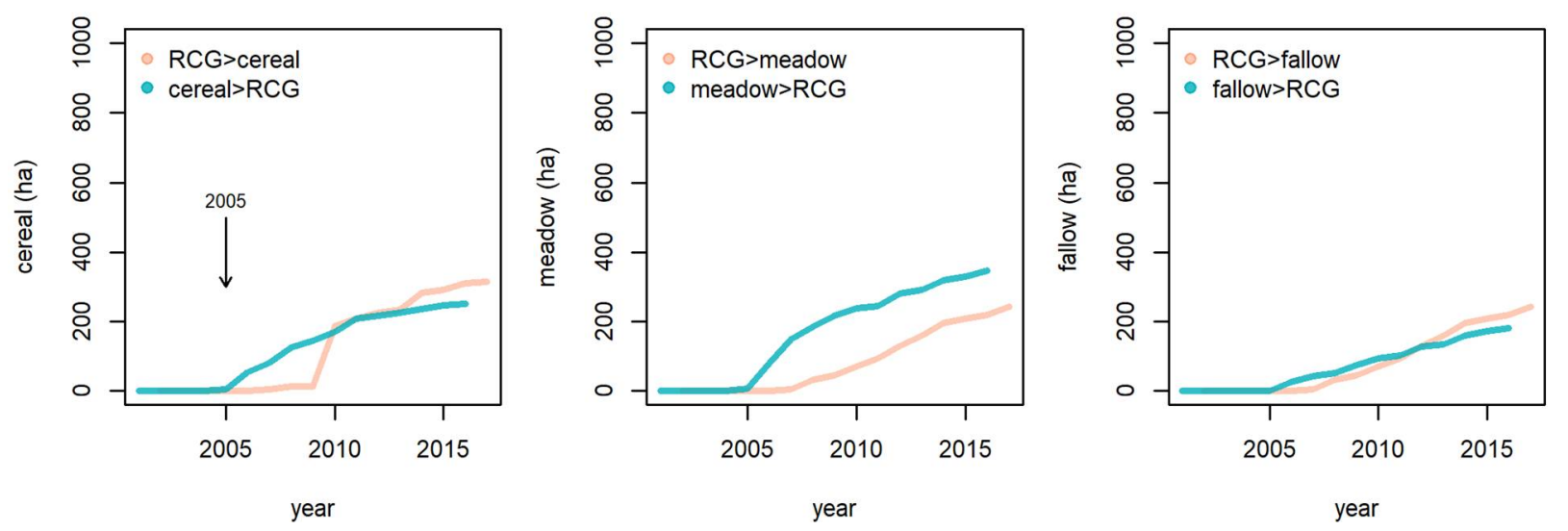

Figure 6. Changes in land use related to reed canary grass (RCG) used for energy in Sweden. The line cereal $>R G C$ refers to the area with cereal replaced by RCG, and RCG > cereal refers to plantations being abandoned and replaced by cereal fields and likewise for meadow and fallow land.

\section{Discussion}

RCG has had a long history in Sweden. This study aims at providing a detailed overview of the crop based on multiple sources of different character. The crop is also compared with the other two existing lignocellulosic biomass production systems, willow and poplar (including hybrid aspen), grown in the country. 
In 1991, the area with RCG peaked at around 4000-5000 ha, mainly used for forage [17]. The expansion was driven by earlier support schemes for converting land from food into non-food crops [19]. These early incentives were established in order to deregulate the agricultural sector, reduce the overplanted food crop areas, and restructure agricultural land use. Subsidies for energy crops were introduced as a compensation tool in the period 1991-1996 [41], stimulating the establishment of energy crops such as willow and opening up the use of RCG for energy rather than fodder [13,42]. As bioenergy markets had not matured before the incentives were removed in the mid-1990s, combined with increased food crop subsidies, the area of both crops decreased [41], leading to the stagnation of new willow plantation areas and the removal of most of the RCG established by that time.

According to the results, by the beginning of the 2000s, there were less than 800 ha of RCG in Sweden compared to over 10,000 ha of willow and 1000 ha poplar in the same period [30]. There was a steady decline that almost supposed the removal of all cultivated area in 2005 , followed by a new rapid expansion, reaching nearly 1000 ha by 2009 . The same increment was observed in Finland, parallel to subsidies and policy incentives for its cultivation, which resulted in about 20,000 ha by 2009 [34]. In 2009, the set-aside requirement, i.e., the EU requirement for farmers producing high quantities of cereals to leave a percentage of their land (ca. 10\%) out of production or grow it with industrial crops, was decided to be removed [43], which is one explanation for the progressive decline after that period.

Concerning productivity, RCG compares well with the other lignocellulosic energy crops in the country [32]. Yields from experiments are at similar ranges for all three crops compared and are at similar levels as indicated in other studies in Finland, Estonia, and Lithuania, with spring harvest yields of ca. $6 \mathrm{odt} \mathrm{ha}^{-1}$ year $^{-1}$ [44-46]. These levels must be taken as an upper threshold in optimal management conditions, as yield observations resulting from experimental plots tend to largely overestimate commercial levels [31]. In addition, there are important harvest losses, which are significant in this case; the effective harvest yield can be only $45 \%-56 \%$ of the biological yields [12,47]. In fact, the results confirm this divergence, as the official commercial averages for Sweden and for Finland (in similar climatic regions) are ca. 50\% lower (3.3-3.5 odt ha ${ }^{-1}$ year $\left.^{-1}\right)$. The resulting yields match the commercial averages for willow [48], indicating a similar performance of both energy crops in terms of biomass.

This can be seen as a competitive advantage: RCG has a lower establishment cost compared with willow plantations [20], and it is growing in less favourable areas for agriculture than other energy crops (the results reflect shorter growing seasons and less cereal productivity than the areas where poplar or willow are planted) thus replacing less fertile land. However, at the same time, the abrupt changes in planting areas suggest the crop is more sensitive than willow to the regulations derived from the policy framework. This is also confirmed by previous studies highlighting that farmers' willingness to grow RCG is highly sensitive to subsidy levels [49]. This could be related to the lower establishment costs, limiting potential losses when abandoned earlier, and to the shorter lifespan, around 10 years, while willow cultivation extends over 25 years [50]. A more dramatic example took place in Finland in the same period of study, as the plantation area decreased from ca. 19,000 ha (2007) to merely 6600 ha (2013) and further down to 3000 ha $(2020)[34,51]$.

It is noticeable, however, that although the total area cultivated in Finland decreased abruptly, the total number of farms cultivating RCG remained stable, from 367 (2013) to 317 (2019), a reduction by a factor of 2 in area but only by $15 \%$ in the number of farms [34]. This suggests that farmers already cultivating RCG decided to continue growing it after the subsidies were removed but chose to reduce the land dedicated to the crop. Overall, the dependency on subsidies can be explained by the narrow economic margins of the crop. Larsson [13] estimated that the minimum farm gate price of RCG required for being profitable would be 56 Swedish krona (SEK) $\mathrm{MWh}^{-1}$ at that time in Sweden. Whereas transportation cost could be reduced by baling [52], losses still occurred due to outdoor storage, especially in long rainy and snowy seasons [19]. In addition, management costs 
can be relatively high when RCG is established on marginal land due to, e.g., deep soil preparation [53].

There were ambitious plans for the expansion of RCG cultivation. For example, the area nearby Skellefteå planned to expand to 3000 ha of RCG in the late 2000s [16,54], and in Finland, it was expected to reach 100,000 ha by 2015 [55,56], which in both cases did not occur since most of the policy incentives were removed before these goals were reached. Additional challenges that precluded RCG from reaching these levels include larger-thanexpected harvest losses and lower fuel quality in terms of lower heat values [57], higher ash content, and higher alkaline concentrations, increasing corrosion risks for the boiler [17]. In addition, RCG has a negative perception among some farmers [49], and it is often regarded as an invasive species [3].

Notwithstanding the negative perception, RCG can have multiple positive environmental effects. Besides the production of sustainable biomass, it has demonstrated its role in carbon sequestration [58], enabling a net carbon sink on organic soils [59]. The effect on soil carbon is, however, dependent on the land where it is established (e.g., [60]). For example, positive effects on soil carbon can, in general, be expected when established on former cropland, while such effects should be less significant when established on previous pastures. The results show that RCG was originally established on previous meadows although, after a few years, many plantations were being replaced by cereals. This pattern is likely linked to the changes related to set-aside land as well as the increase in cereal prices after 2007, as observed in Xu and Mola-Yudego [30]; the larger implications of this land-use change pattern should be subject to further study.

Despite some studies suggesting its landscape dominance to have a negative effect on biodiversity for their invasive character [61], the typical cultivation in small areas separated by other land uses (with due planning and control) may indeed favour a mosaicbased land-use pattern, creating diverse niches for fauna and flora [62]. In addition, the strategic introduction of perennial crops into agricultural landscapes can, in general, result in multiple positive effects by supporting ecosystem services that can mitigate existing environmental impacts related to, e.g., soil and water, while supposing minor effects on food production $[4,63,64]$. For instance, the potential of RCG to mitigate GHG emissions from abandoned peat extraction areas has been shown [65].

The success of RCG will depend on a predictable and sustainable economic profit for the farmers. In general, further cost reduction in management practices and higher revenues in terms of energy prices will be required in order to avoid the excessive dependence on direct policy incentives. Technical and management aspects related to the reduction of harvesting losses can also contribute to a better economic output. Finally, financial compensation for environmental benefits associated with its cultivation would enable the crop to compete with fallow land when grown on marginal land, which is usually the case in Sweden [14].

\section{Conclusions}

Compared to willow and poplar cultivation in Sweden, RCG presents good commercial yields despite harvesting losses and being established on less productive locations. The different profiles of the three main biomass production systems for energy show regional complementary features. However, there are important limitations that prevent the expansion of the crop, such as insufficient markets for the biomass and lack of compensation for environmental benefits; the establishment of new plantations is, therefore, currently highly sensitive to direct support schemes. Finally, there are ongoing land-use trends towards cereal cultivation, possibly due to more favourable prices. The analysis provided in the study concerning cultivation areas, land use, yield performance, and climatic profiles can serve as a basis for future analysis of the status of energy crops in Northern Europe and elsewhere. 
Author Contributions: Conceptualization, B.M.-Y. and X.X.; methodology, B.M.-Y. and X.X.; software, B.M.-Y. and X.X.; validation, B.M.-Y. and X.X.; formal analysis, B.M.-Y. and X.X.; investigation, B.M.Y. and X.X.; resources, B.M.-Y. and X.X.; data curation, B.M.-Y. and X.X.; writing-original draft preparation, B.M.-Y., X.X., I.D. and O.E.; writing-review and editing, B.M.-Y., X.X., I.D. and O.E.; visualization, B.M.-Y. and X.X.; supervision, B.M.-Y., I.D.; project administration, B.M.-Y.; funding acquisition, B.M.-Y., X.X. and I.D. All authors have read and agreed to the published version of the manuscript. B.M.-Y. and X.X. shared first authorship.

Funding: This research was funded by IEA Task 43 Bioenergy and Niemi foundation, grant number 20200009.

Data Availability Statement: The original data can be found in the cited publications; the maps and land uses data is available at https://jordbruksverket.se/.

Acknowledgments: We would like to thank Gerda Landell at Statistics Sweden for her kind contribution to the data used in the paper and to Seikh Sharif for his help compiling trial data. Finally, we thank the help and support by the IEA Bioenergy Task 43 and the Niemi foundation.

Conflicts of Interest: The authors declare no conflict of interest.

\section{References}

1. Lewandowski, I.; Scurlock, J.M.; Lindvall, E.; Christou, M. The development and current status of perennial rhizomatous grasses as energy crops in the US and Europe. Biomass Bioenergy 2003, 25, 335-361. [CrossRef]

2. Antonkiewicz, J.; Kołodziej, B.; Bielińska, E.J. The use of reed canary grass and giant miscanthus in the phytoremediation of municipal sewage sludge. Environ. Sci. Pollut. Res. 2016, 23, 9505-9517. [CrossRef]

3. Lavergne, S.; Molofsky, J. Reed canary grass (Phalaris arundinacea) as a biological model in the study of plant invasions. Crit. Rev. Plant Sci. 2004, 23, 415-429. [CrossRef]

4. Englund, O.; Börjesson, P.; Berndes, G.; Scarlat, N.; Dallemand, J.F.; Grizzetti, B.; Dimitriou, I.; Mola-Yudego, B.; Fahl, F. Beneficial land use change: Strategic expansion of new biomass plantations can reduce environmental impacts from EU agriculture. Glob. Environ. Chang. 2020, 60, 101990. [CrossRef]

5. Jasinskas, A.; Streikus, D.; Šarauskis, E.; Palšauskas, M.; Venslauskas, K. Energy evaluation and greenhouse gas emissions of reed plant pelletizing and utilization as solid biofuel. Energies 2020, 13, 1516. [CrossRef]

6. Roj-Rojewski, S.; Wysocka-Czubaszek, A.; Czubaszek, R.; Kamocki, A.; Banaszuk, P. Anaerobic digestion of wetland biomass from conservation management for biogas production. Biomass Bioenergy 2019, 122, 126-132. [CrossRef]

7. Tilvikiene, V.; Kadziuliene, Z.; Dabkevicius, Z.; Venslauskas, K.; Navickas, K. Feasibility of tall fescue, cocksfoot and reed canary grass for anaerobic digestion: Analysis of productivity and energy potential. Ind. Crop. Prod. 2016, 84, 87-96. [CrossRef]

8. Alhumade, H.; da Silva, J.C.G.; Ahmad, M.S.; Çakman, G.; Yıldı, A.; Ceylan, S.; Elkamel, A. Investigation of pyrolysis kinetics and thermal behavior of Invasive Reed Canary (Phalaris arundinacea) for bioenergy potential. J. Anal. Appl. Pyrolysis 2019, 140, 385-392. [CrossRef]

9. Scordia, D.; Cosentino, S.L. Perennial energy grasses: Resilient crops in a changing European agriculture. Agriculture 2019, 9, 169. [CrossRef]

10. Lankoski, J.; Ollikainen, M. Bioenergy crop production and climate policies: A von Thunen model and the case of reed canary grass in Finland. Eur. Rev. Agric. Econ. 2008, 35, 519-546. [CrossRef]

11. Mikkola, H.J.; Ahokas, J. Renewable energy from agro biomass. Agron. Res. 2011, 9, 159-164.

12. Pahkala, K.; Aalto, M.; Isolahti, M.; Poikola, J.; Jauhiainen, L. Large-scale energy grass farming for power plants-A case study from Ostrobothnia, Finland. Biomass Bioenergy 2008, 32, 1009-1015. [CrossRef]

13. Larsson, S. Supply curves of reed canary grass (Phalaris arundinacea L.) in Västerbotten County, northern Sweden, under different EU subsidy schemes. Biomass Bioenergy 2006, 30, 28-37. [CrossRef]

14. Nilsson, D.; Rosenqvist, H.; Bernesson, S. Profitability of the production of energy grasses on marginal agricultural land in Sweden. Biomass Bioenergy 2015, 83, 159-168. [CrossRef]

15. Alway, F.J. Early trials and use of reed-canary grass as a forage plant. J. Am. Soc. Agron. 1931, 23, 64-66. [CrossRef]

16. Finell, M. The Use of Reed Canary-Grass (Phalaris arundinacea) as a Short Fibre Raw Material for the Pulp and Paper Industry. Ph.D. Thesis, Swedish University of Agricultural Sciences, Umeå, Sweden, 2003. Available online: http://urn.kb.se/ resolve?urn=urn: nbn:se:slu:epsilon-95 (accessed on 16 January 2021).

17. Landfors, K.; Hollsten, R. Energigräs-en Kunskapssammanställning; Jordbruksverket: Jönköping, Sweden, 2011; 20p. (In Swedish)

18. Landström, S.; Lomakka, L.; Andersson, S. Harvest in spring improves yield and quality of reed canary grass as a bioenergy crop. Biomass Bioenergy 1996, 11, 333-341. [CrossRef]

19. Venendaal, R.; Jørgensen, U.; Foster, C.A. European energy crops: A synthesis. Biomass Bioenergy 1997, 13, 147-185. [CrossRef]

20. Shield, I.F.; Barraclough, T.J.P.; Riche, A.B.; Yates, N.E. The yield response of the energy crops switchgrass and reed canary grass to fertiliser applications when grown on a low productivity sandy soil. Biomass Bioenergy 2012, 42, 86-96. [CrossRef]

21. Lindvall, E. Nutrient Supply to Reed Canary Grass as a Bioenergy Crop. Acta Univ. Agric. Suec. 2014, 54, 53. 
22. Lewandowski, I. Biomass Production from Lignocellulosic Energy Crops. In Encyclopedia of Applied Plant Sciences; Thomas, B., Murray, B.G., Murphy, D.J., Eds.; Elsevier: Amsterdam, Netherlands, 2017; pp. 159-163, ISBN 978-0-12-394808-3.

23. Lindvall, E.; Gustavsson, A.M.; Samuelsson, R.; Magnusson, T.; Palmborg, C. Ash as a phosphorus fertilizer to reed canary grass: Effects of nutrient and heavy metal composition on plant and soil. GCB Bioenergy 2015, 7, 553-564. [CrossRef]

24. Pahkala, K.; Partala, A.; Suokannas, A.; Klemola, E.; Kalliomäki, T.; Kirkkari, A.M.; Flyktman, M. Odling och Skörd av Rörflen för Energiproduktion; MTT: Jokioinen, Finland, 2003; 27p, ISBN 951-729-744-0. (In Swedish)

25. Lindvall, E.; Gustavsson, A.M.; Palmborg, C. Establishment of reed canary grass with perennial legumes or barley and different fertilization treatments: Effects on yield, botanical composition and nitrogen fixation. GCB Bioenergy 2012, 4, 661-670. [CrossRef]

26. Kandel, T.P.; Elsgaard, L.; Karki, S.; Lærke, P.E. Biomass yield and greenhouse gas emissions from a drained fen peatland cultivated with reed canary grass under different harvest and fertilizer regimes. BioEnergy Res. 2013, 6, 883-895. [CrossRef]

27. Xiong, S.; Zhang, Q.G.; Zhang, D.Y.; Olsson, R. Influence of harvest time on fuel characteristics of five potential energy crops in northern China. Bioresour. Technol. 2008, 99, 479-485. [CrossRef] [PubMed]

28. Larsson, S.H.; Thyrel, M.; Geladi, P.; Lestander, T.A. High quality biofuel pellet production from pre-compacted low density raw materials. Bioresour. Technol. 2008, 99, 7176-7182. [CrossRef] [PubMed]

29. JBB, Swedish Board of Agriculture (Jordbruksverket). Kartor och Geografiska Informations System. Available online: https: / / nya.jordbruksverket.se/ (accessed on 20 November 2019). (In Swedish)

30. Xu, X.; Mola-Yudego, B. Where and when are plantations established? Land-use replacement patterns of fast-growing plantations on agricultural land. Biomass Bioenergy 2021, 144, 105921. [CrossRef]

31. Mola-Yudego, B.; Díaz-Yáñez, O.; Dimitriou, I. How much yield should we expect from fast-growing plantations for energy? Divergences between experiments and commercial willow plantations. BioEnergy Res. 2015, 8, 1769-1777. [CrossRef]

32. Dimitriou, I.; Mola-Yudego, B. Poplar and willow plantations on agricultural land in Sweden: Area, yield, groundwater quality and soil organic carbon. For. Ecol. Manag. 2017, 383, 99-107. [CrossRef]

33. Eurostat 2021, Crop Production in EU Standard Humidity, Code: Apro_cpsh1. Available online: https:/ / ec.europa.eu/eurostat (accessed on 6 April 2021).

34. LUKE 2021, Natural Resources Institute Finland, Statistical Databases, Crop Production Statistics, Luke_Maa_Sato_0. Available online: www.statdb.luke.fi (accessed on 6 April 2021).

35. Swedish Official Statistics, Standard Yields for Yield Survey Districts, Counties and the Whole Country, Several years). Available online: https: / / www.scb.se (accessed on 23 October 2019). (In Swedish)

36. Fick, S.E.; Hijmans, R.J. WorldClim 2: New 1-km spatial resolution climate surfaces for global land areas. Int. J. Climatol. 2017, 37, 4302-4315. [CrossRef]

37. Worton, B.J. Kernel methods for estimating the utilization distribution in home-range studies. Ecology 1989, 70, 164-168. [CrossRef]

38. Silverman, B.W. Density Estimation for Statistics and DATA Analysi; CRC Press: Boca Raton, FL, USA, 1986 ; Volume 26.

39. Mola-Yudego, B.; González-Olabarria, J.R. Mapping the expansion and distribution of willow plantations for bioenergy in Sweden: Lessons to be learned about the spread of energy crops. Biomass Bioenergy 2010, 34, 442-448. [CrossRef]

40. Jordbruksverket. Stöd för Odling av Grödor för Industri- och Energiändamål; Jönköping, Sweden, 2008; 24p. Available online: http:/ / www2.jordbruksverket.se/webdav / files/SJV/trycksaker/Jordbruksstod/JS13.pdf (accessed on 26 January 2021). (In Swedish)

41. Hadders, G.; Olssen, R. European Energy Crops Overview, Country Report for Sweden. 1996. Available online: https:/ /www. diva-portal.org/smash/get/diva2:959639/FULLTEXT01.pdf (accessed on 26 January 2021).

42. Mola-Yudego, B.; Pelkonen, P. The effects of policy incentives in the adoption of willow short rotation coppice for bioenergy in Sweden. Energy Policy 2008, 36, 3062-3068. [CrossRef]

43. Official Journal of the European Union. Communication from the Commission to All Farmers Concerning Set Aside from 2009 (2008/C 324/07). 2008. Available online: https:/ / eur-lex.europa.eu/LexUriServ/LexUriServ.do?uri=OJ:C:2008:324:0011:0011:EN: PDF (accessed on 26 January 2021).

44. Pahkala, K.; Pihala, M. Different plant parts as raw material for fuel and pulp production. Ind. Crop. Prod. 2000, 11, 119-128. [CrossRef]

45. Heinsoo, K.; Hein, K.; Melts, I.; Holm, B.; Ivask, M. Reed canary grass yield and fuel quality in Estonian farmers' fields. Biomass Bioenergy 2001, 35, 617-625. [CrossRef]

46. Jasinskas, A.; Zaltauskas, A.; Kryzeviciene, A. The investigation of growing and using of tall perennial grasses as energy crops. Biomass Bioenergy 2008, 32, 981-987. [CrossRef]

47. Lötjönen, T.; Paappanen, T. Bale density of reed canary grass spring harvest. Biomass Bioenergy 2013, 51, 53-59. [CrossRef]

48. Mola-Yudego, B.; Aronsson, P. Yield models for commercial willow biomass plantations in Sweden. Biomass Bioenergy 2008, 32, 829-837. [CrossRef]

49. Paulrud, S.; Laitila, T. Farmers' attitudes about growing energy crops: A choice experiment approach. Biomass Bioenergy 2010, 34, 1770-1779. [CrossRef]

50. Börjesson, P. Environmental effects of energy crop cultivation in Sweden-I: Identification and quantification. Biomass Bioenergy 1999, 16, 137-154. [CrossRef]

51. TIKE. Yearbook of Farm Statistics, Utilized Agricultural Area, 2001-2007; ISSN: Helsinki, Finland, 2007. 
52. Lindh, T.; Paappanen, T.; Rinne, S.; Sivonen, K.; Wihersaari, M. Reed canary grass transportation costs—Reducing costs and increasing feasible transportation distances. Biomass Bioenergy 2009, 33, 209-212. [CrossRef]

53. Larsson, S.; Nilsson, C. A remote sensing methodology to assess the costs of preparing abandoned farmland for energy crop cultivation in northern Sweden. Biomass Bioenergy 2005, 28, 1-6. [CrossRef]

54. Olsson, J.; Salomon, E.; Baky, E.; Palm, O. Energigrödor-en Möjlighet för Jordbruksanvändning av Slam; Svenskt Vatten Utveckling, Svenskt Vatten AB: Bromma, Sweden, 2008; Volume 12, p. 53. (In Swedish)

55. MMM, (Ministry of Agriculture and Forestry). Press Release Interim Report. 2006. Available online: https://mmm.fi/sv/-/ ruokohelven-viljelyala-noussut-nopeasti-suomessa (accessed on 26 January 2006).

56. Hyvönen, N.P.; Huttunen, J.T.; Shurpali, N.J.; Tavi, N.M.; Repo, M.E.; Martikainen, P.J. Fluxes of nitrous oxide and methane on an abandoned peat extraction site: Effect of reed canary grass cultivation. Bioresour. Technol. 2009, 100, 4723-4730. [CrossRef] [PubMed]

57. Burvall, J. Influence of harvest time and soil type on fuel quality in reed canary grass (Phalaris arundinacea L.). Biomass Bioenergy 1997, 12, 149-154. [CrossRef]

58. Xiong, S.; Kätterer, T. Carbon-allocation dynamics in reed canary grass as affected by soil type and fertilization rates in northern Sweden. Acta Agric. Scand. Sect. B Soil Plant Sci. 2010, 60, 24-32. [CrossRef]

59. Shurpali, N.J.; Hyvönen, N.P.; Huttunen, J.T.; Clement, R.J.; Reichstein, M.; Nykänen, H.; Nykänen, H.; Biasi, C.; Martikainen, P.J. Cultivation of a perennial grass for bioenergy on a boreal organic soil-carbon sink or source? GCB Bioenergy 2009, 1, 35-50. [CrossRef]

60. Krol, D.J.; Jones, M.B.; Williams, M.; Choncubhair, O.N.; Lanigan, G.J. The effect of land use change from grassland to bioenergy crops Miscanthus and reed canary grass on nitrous oxide emissions. Biomass Bioenergy 2019, 120, 396-403. [CrossRef]

61. Spyreas, G.; Wilm, B.W.; Plocher, A.E.; Ketzner, D.M.; Matthews, J.W.; Ellis, J.L.; Heske, E.J. Biological consequences of invasion by reed canary grass (Phalaris arundinacea). Biol. Invasions 2010, 12, 1253-1267. [CrossRef]

62. Hersperger, A.M. Spatial adjacencies and interactions: Neighborhood mosaics for landscape ecological planning. Landsc. Urban Plan. 2006, 77, 227-239. [CrossRef]

63. Englund, O.; Börjesson, P.; Mola-Yudego, B.; Berndes, G.; Dimitriou, I.; Cederberg, C.; Scarlat, N. Beneficial Land-Use Change in Europe: Deployment Scenarios for Multifunctional Riparian Buffers and Windbreaks. 2021. Available online: https://www. researchsquare.com/article/rs-128604/v1 (accessed on 10 May 2021). [CrossRef]

64. Englund, O.; Dimitriou, I.; Dale, V.H.; Kline, K.L.; Mola-Yudego, B.; Murphy, F.; English, B.; McGrath, J.; Busch, G.; Negri, M.C.; et al. Multifunctional perennial production systems for bioenergy: Performance and progress. Wiley Interdiscip. Rev. Energy Environ. 2020, 9, e375. [CrossRef]

65. Mander, Ü.; Järveoja, J.; Maddison, M.; Soosaar, K.; Aavola, R.; Ostonen, I.; Salm, J.O. Reed canary grass cultivation mitigates greenhouse gas emissions from abandoned peat extraction areas. GCB Bioenergy 2012, 4, 462-474. [CrossRef] 